\title{
WORLD LITERATURE ON THE DESTINY AND SUFFERINGS OF JEWISH PEOPLE
}

\author{
CMukhamedova Sh., ORCID: 0000-0002-3685-3051, Uzbekistan State University of World \\ Languages, Tashkent, Uzbekistan, obidjonova993@gmail.com
}

\section{МИРОВАЯ ЛИТЕРАТУРА О СУДЬБЕ И СТРАДАНИЯХ ЕВРЕЙСКОГО НАРОДА}

\author{
СМухамедова ШІ. У., ORCID: 0000-0002-3685-3051, Узбекский государственный \\ университет мировых языков, г. Ташкент, Узбекистан, obidjonova993@gmail.com
}

Abstract. The article considers the Holocaust reflection in world literature and popular authors as the best painters of the Holocaust repressions. Naturally, the Holocaust is a trauma which cannot ever be restored, a gap that cannot be bridged. Down to the present day, this remains an important topic for discussion. Despite the overwhelming persecution and death that surrounded the Jewish nation, hundreds of thousands of Jews survived the nightmare of the Holocaust. In order to integrate the past in their lives, survivors want to testify and/or write down their experiences. These stories of survival provide the only glimpse of 'goodness' that comes from the terrible story of the Holocaust. It proves that, even in history's darkest hour, there was a glimmer of hope; that in a world that seemed to be falling apart, good still had the capacity to overcome evil. All stories written on the destiny and sufferings of the Jewish nation are worth analysis. However, we took only those which are in the form of confession. The chosen novels can be classified by the types of the central heroes and heroes have been divided into subgroups according to their age, nation, and, of course, the gender. The article aims to reaffirm the importance of the novels by using three literary approaches - historical, biographical and social. The biographical approach is taken for the analysis to identify the link between the work and the authors, who build a story on the basis of their own memories and real-life experience. Furthermore, the socio-historical problems highlighted in the novels are very relevant, since they still exist in modern societies in one or another form. The article reflects how even one novel encompasses morality, dignity, humanity issues and at the same time reveals the author's position related to the indifference of the world regarding cruelty and evading responsibility for anti-human crimes along with how to avoid them in the near future.

Аннотащия. Рассматривается отражение Холокоста в мировой литературе и популярных авторов, как лучших художников репрессий Холокоста. Холокост - травма, которую невозможно забыть и преодолеть. На сегодняшний день, он остается важной темой для обсуждения. Несмотря на преследование и убийств, окружавшей еврейский народ, сотни тысяч евреев пережили кошмар Холокоста. Для того, чтобы внедрить прошлое в свою жизнь, выжавшие готовы свидетельствовать и написать свой опыт в строках. Эти истории выживания дают единственный проблеск «добра», который исходит из ужасной истории Холокоста. Это доказывает, что даже в самый мрачный час истории был проблеск надежды; что в мире, который, казалось, разваливался на части, добро все еще было способно победить зло. Все истории, написанные о судьбе и страданиях еврейского народа, заслуживают анализа. Однако мы взяли только те, которые находятся в форме признание. Выбранные романы можно классифицировать по типам центральных героев, а герои были разделены на подгруппы в зависимости от их возраста, национальности и, конечно же, пола. Цель статьи - подтвердить значимость романов с помощью трех литературных подходов - 
исторического, биографического и социального. Биографический подход используется для анализа с целью выявления связи между произведением и авторами, которые строят рассказ на основе собственных воспоминаний и реального жизненного опыта. Кроме того, социально-исторические проблемы, освещаемые в романах, весьма актуальны, поскольку они все еще существуют в современных обществах в той или иной форме. В статье отражено, как даже в одном романе затрагиваются вопросы морали, достоинства, гуманности и одновременно раскрывается авторская позиция, связанная с безразличием мира к жестокости и уклонению от ответственности за антигуманные преступления, а также с тем, как избежать их в ближайшем будущем.

Keywords: Holocaust, historical approach, biographical approach, social approach, Nazi regime, separatism.

Ключевые слова: Холокост, исторический подход, биографический подход, социальный подход, нацистский режим, сепаратизм.

Literature is the mirror of one or another nation, because it reflects how people lived or live, how they earn to make a living, their interests, how people reacted at a certain situation and etc. The literature, which is considered as one of the most prominent and widely ranged forms of art would surely reflect history that we went through.

This article deals with the Holocaust reflection in the world, literature having complicated relationships. The Holocaust has influenced, if not defined, nearly every Jewish writer since, from Saul Bellow to Jonathan Safran Foer, and many non-Jews besides, like W.G. Sebald and Martha Hall Kelly and other writers all over the world. As an American novelist and researcher Menachem Kaiser stands, literature via art is still innately concerned with representation and appropriation seemingly stands opposed to the immutability of the Holocaust and our oversized obligations to its memory. We agree that good piece of fiction has artistic demands, flexes and contorts narratives, resists clear morality, compromises reality's details. Regarding the Holocaust, this seems unconscionable, even irreligious.

After the end of the World War I, fascism rose out of relative obscurity into international prominence, with fascist regimes forming most notably in Italy, Germany, and Spain, the three of which would be allied in the World War II. Fascist Benito Mussolini seized power in Italy in 1922 and Adolf Hitler had successfully consolidated his power in Germany by 1933, Franco in Spain in 1936.

It is obvious that literature could not help reacting to it quickly. The Holocaust was one of the world's darkest hours - a mass murder of Jewish nation conducted in the shadows of the Second World War. The word Holocaust as a term has its own history, being taken from the Greek language. It encompasses the words "holo" (whole) and "kaustos" (burned) and is used to describe a sacrificial offering burned on an altar. Then the meaning transferred to nominate the process of mass extermination of Jewish nation initiated by Nazi regime during WWII. The German government, controlled by the brutal Nazi Party and its leader Adolf Hitler, killed between five and six million Jews who lived in Europe. These were not the only victims, however. They were murdered because of Germany's fanatical racial policies. It did not matter their age - millions were children. Their social status or educational background did not matter - they were doctors and lawyers, laborers and tradesmen. It mattered only that they were considered "enemies of the state", a threat to the "purity" of the German race and the greatness of the German empire. "In addition to Jews and Gypsies, they were Poles, Jehovah's Witnesses, the mentally disabled, the physically 
handicapped, political opponents, homosexuals, and others deemed "unworthy of life." Remembering the Holocaust is essential for all generations" [1].

\section{Problem development status}

People have complicated relations with each other for centuries. But why exactly during WWII it comes to the pick point? An answer is the indifference of the world and ignorance of people towards other nations. Jewish people similar to other oppressed people could not act and remain strong against the force and repression of the Nazi regime. However, under the most adverse conditions, Jewish prisoners succeeded in initiating resistance and uprisings in some Nazi camps. The surviving Jewish workers launched uprisings even in the killing centers of Treblinka, Sobibor, and Auschwitz-Birkenau, some of which were successful. However, the Nazis executed many prisoners as punishment and as a warning to others.

In 1982, German philosopher and sociologist Theodore Adorno uttered the famous words "Nach Auschwitz ein Gedicht zu schreiben ist barbarisch", which means "writing a poem after Auschwitz is barbaric". He claims that using the Holocaust to create an aesthetic representation can be seen as a form of victim abuse. Poetry and literature create "works of art" and this pleasurable principle contrasts strongly with the horrific nature of the event itself: people take pleasure in reading poems or books and this adds injustice to all those millions of Jews who have been murdered. Nevertheless, we should consider the paradoxical nature of his statement. In his essay on Commitment Adorno mentions the fact that the suffering of all the Holocaust victims needs to be remembered but "that suffering also demands the continued existence of the very art it forbids". Foremost, we must also consider that a written account of someone's experiences can never convey the harsh reality of the original experience. Authors try to represent what has happened but as a reader, you will never really know or feel how a Holocaust victim has felt during this period. Authors portraying the "crime of century" succeed in approaching the cockles of each readers' heart and give a chance to imagine under what oppressions Jews all over the world have gone through due to Nazi's philosophy of Aryanism.

Berel Lang, an American philosophy educator, talks about "representations" [2], hereby he wants to make clear that all representations can be perceived as subjective. Someone who survived the Holocaust will claim that it should be considered as living hell, while from a German point of view it can be claimed that the Holocaust could be perceived as a career opportunity.

If there are several possible representations and none can convey the suffering of the lived experience, should people try to represent the facts? Of course, there are many different opinions on whether or not the Holocaust should be dealt with via literature. One reason that seems to reappear regularly is the fact that the events are simply too horrifying in nature. Robert Leventhal, an associate professor of German Studies at Stanford University said "The atrocities committed by the Nazi regime...transcend any words we could use to characterize them. Their barbarity goes beyond the referential and representational capacity of language". [3] So the horrors of Auschwitz and Buchenwald are no exceptions as they need no artistic intensification. A great deal of diaries, novels, dramas, poetic works, and memoires describing horrors of life of Jewish people before and in such concentration camps naturally gave birth to the Holocaust literature, which now does not lose its power to interact audiences. "Capturing both individual and collective experiences, narrating events from a subjective and of necessity limited standpoint, memoirs about the Holocaust occupy a space between imaginative literature and history" [4].

Primo Levi, an Italian Jewish poet and novelist divides the group of the Holocaust survivors into two categories; "those who remain silent and those who speak". Because of the traumatizing nature of the events, people have often preferred to repress their memories. Nevertheless, their silenced memory did not fade overtime. Within this view, Charlotte Delbo, a French writer who has 
been in Auschwitz as a prisoner talks about "deep memory". Writing down the experiences of the past can be perceived as a part of a therapeutic process. The act itself of testifying should be perceived as a key element within the process of working through the traumatic past. Detachment from the cruel facts is considered to be a very difficult task but closure is necessary because of the fact that many the Holocaust survivors still seem to live in the past.

Although they function in a modern society, the past seems to haunt them all the time. It must also be remarked that the so-called first generations were not the only ones who felt an urge to talk about the past. Next to the "deep memory", we can also talk about collective memory. Current generations have to deal with a moral and psychological burden. They were no historical participants but most of the times their parents or grandparents were. Subsequently, the members of the second generation and the third generation search for new ways to deal with the Holocaust in modern society.

\section{Material and research methods}

It must be said that the Holocaust literature has often been attacked by the Holocaust deniers. Literature aims at providing knowledge about the Holocaust, authors want to make sure that people know about the events of the past. It does not serve as a tool to undermine the Holocaust. Therefore, authors have a great responsibility in representing it.

Since the Holocaust literature appeared, the memoir, the first-person unembellished account, has long been considered the apotheosis of the form. On the other hand, even, according to some, the only acceptable form - confining the Holocaust literature to documentation and reflexively censuring everything else for crassly misrepresenting the unpresentable. This pushed for the emergence of a new theme - the Holocaust, which exists in the creative works of both Jews and non-Jewish people in different languages of the world. Such works gained popularity because of readers' great interest and eagerness to know the truth what really had happened to Jewish nation as a whole during WWII. Through literature, readers cannot only learn the facts about the Third Reich and the World War II, but they can also make personal connections with those characters, real and fictional, who lived and died during the Holocaust. That's why to reaffirm the importance of the novels depicting Holocaust can be put under analysis by using three literary approaches historical, biographical and social. The biographical approach is taken for the analysis to identify the link between the work and the author, who builds a story on the basis of his own memories and real life experience. Furthermore, the socio-historical problems highlighted in the novels are very relevant, since they still exist in modern societies in one or another form. The article reflects how world famous novels encompass morality, dignity, humanity issues and at the same time reveal the authors' position related to the indifference of the world regarding cruelty and evading responsibility for anti-human crimes along with how to avoid them in the near future.

\section{Results and discussion}

An enormous amount and variety of prosaic works, reflecting the Holocaust theme are available today for study in world literature. Yet, another challenge is to categorize them. The article is devoted to the classification of works in prose reflecting theme of the Holocaust in world literature according to the type of central heroes. Shoah Resource Center which is famous for its International School for The Holocaust Studies, in its article stated Charlotte Delbo and Jorge Semprun are among the best-known non-Jews, Elie Wiesel and Anna Langfus' works are extremely realistic in the depiction of the concentration camps. However, we include several other authors to the research as their stories are presented from various points of heroes.

Primarily, we should enlist our central heroes according to their age, gender and nationality. The variety types of central heroes have a significant influence on the stories about the Holocaust. Table 1 illustrates our chosen types. 


\begin{tabular}{cll}
\hline \multirow{2}{*}{$\begin{array}{c}\text { Central } \\
\text { hero }\end{array}$} & \multicolumn{1}{c}{ Nationality } \\
\cline { 2 - 3 } A boy & $\begin{array}{l}\text { Joy in Striped Pyjamas (2006) by John Boyne; } \\
\text { Prisoner B-308 (2013) by Alan Gratz. }\end{array}$ & \multicolumn{1}{c}{ German } \\
\hline \multirow{2}{*}{ A man } & $\begin{array}{l}\text { Survival in Auschwitz (or If This Is a Man), (1947) by Primo } \\
\text { Levi; } \\
\text { The Last Jew of Treblinka (2009) Chil Rajchman. }\end{array}$ & $\begin{array}{l}\text { Schindler's Ark (1982) by } \\
\text { Thomas Keneally }\end{array}$ \\
\hline \multirow{2}{*}{ A girl } & $\begin{array}{l}\text { The Diary of Young Girl (1947) by Anne Frank; } \\
\text { The Book Thief (2005) by Markus Zusak }\end{array}$ & - \\
\hline A woman & Born Survivors (2015) by Wendy Holden & $\begin{array}{l}\text { Irena's Children (2016) by } \\
\text { Tilar J. Mazzeo }\end{array}$ \\
\hline Animated & Maus (1991) by Art Spiegelman & - \\
\hline
\end{tabular}

The novel Boy in Striped Pyjamas (2006) written by John Boyne (1971), an Irish novelist, gains popularity among readers who are not indifferent to the Holocaust theme. The admiration can be explained by the author's choice to show the fate of Jews through the 9 years-old boy's eyes. Young boys become the focus of the author, he organizes the meeting of two innocent souls who do not know the war, have not any idea of anti-Semitism, who cannot even imagine what is the death. The novel demonstrates how different people's life can be lived, depending on what nation they belong to. Two boys - a German boy, Bruno, and a Jewish boy, Shmuel became friends; however, there was a fence between them. It is because Shmuel lives in the death camp, in Auschwitz, wears blue and white striped pyjamas. Bruno, on the contrary, lives in a big mansion. The novel makes people stop and think about scarified lives of pure hearts because of the Holocaust. Another novel Prisoner B-3087 (2013) by Alan Gratz (1972), an American author of young adults, who portrayed Jewish boy Yanek from Poland during 1930s. Yanek Gruener, the central hero, has lost everything he had, and everyone he loved were snatched brutally from him. Then Yanek himself was taken a prisoner - his arm tattooed with the words PRISONER B-3087. He was forced from one nightmarish concentration camp to another, as the World War II raged all around him. He encountered evil he could have never imagined, but also saw surprising glimpses of hope amid the horror. He just barely escapes death, only to confront it again seconds later. The author describes Yanek how the boy goes through the terror without losing his hope, his will - and, most of all, his sense of who he really is inside after he faces ten concentration camps, ten different places where he is starved, tortured, and worked mercilessly.

Naturally, the world outlook of a boy and an adult differs, as the latter is more mature and has sustainable education along with life experience over his shoulder comparing to former. Thus stories on the Holocaust narrated by grown-ups, for instance, by a man, carry more complex and detailed nature relating to above-mentioned factors. The novel Survival in Auschwitz (or If This Is a Man), is a vivid example of the Holocaust retold by an Italian Jewish poet Primo Levi (1919-1987). The novel, first published in 1947, describes the arrest of a poet as a member of the Italian antifascist resistance during the Second World War, and his incarceration in the Auschwitz concentration camp from February 1944 until the camp was liberated on January 27, 1945. Levi's experience during the repression and anti-human treatments by Nazi regime is clearly demonstrated in the novel. The next novel The Last Jew of Treblinka (2009) by Polish-Jewish the Holocaust survivor Chil Rajchman (1914-2004) portrayed his life as a prisoner of the Treblinka extermination camp which took lives of tiny children, old men, beautiful girls - in the gas chambers of Treblinka all were equal. A central $\operatorname{cog}$ in the wheel of Adolf Hitler's Final Solution, the fires of Treblinka were kept burning night and day. Chil Rajchman was 28 when he was brought to Treblinka in 1942. At the extermination camp, he was forced to work as a "barber," shaving the heads of victims, and a "dentist," pulling gold teeth from corpses. But he escaped eleven months later and survived to tell 
the shocking and heartbreaking tale of his experience - and of those who didn't make it out alive. Elie Wiesel calls his memoir as "an important, heart-rending contribution to our search for truth." [2; $p$ 3] Poignant and powerful, this memoir provides the only survivors' record of the horrifying Polish extermination camp. Originally written in Yiddish in 1945, it was published in Paris only in the 21 st century. Without hope or agenda other than to bear witness, Rajchman's story shows that remembering is sometimes the bravest and most painful act of all.

Diaries offer a unique perspective on the events of the Holocaust. Writing diaries is peculiar for a tender gender. Already during the war years, and under the shadow of Nazism, Jewish women gave narrative forms to their experiences, writing wartime diaries and journals. The most famous of these, The Diary of Young Girl (1947) by Anne Frank (1929-1945), takes the form of letters to a confidante and traces the daily life and inner life of an adolescent girl, hiding in a secret room in Holland with her secular German Jewish family. Although Frank was eventually deported to Bergen-Belsen, where she perished, her father later retrieved and edited his daughter's diary, which was published posthumously. This abbreviated diary stressed the universal, rather than the Jewish, aspects of Anne Frank's sensibilities, omitting explicit references to anti-Semitism. "For young readers and adults, it continues to bring to life this young woman, who for a time survived the worst horrors the modern world had seen - and who remained triumphantly and heartbreakingly human throughout her ordeal" [5]. Another novel The Book Thief (2005) centers a girl Liesel Meminger, who not being keen on writing but reading, even goes for stealing a book in order to keep awake of his beloved Jewish friend Max, in their basement. Australian author Markus Zusak (1975) depicts a girl from foster a family living outside of Munich, putting their life into death danger and the family members do their best to save Max's life. The novel touched many themes besides the Holocaust love, friendship, value of a family and others. Moreover, Liesel describes the Jewish terror occurring around her.

Some women, the Holocaust survivors, mediated their experiences through fiction and poetry, utilizing literary and imaginative strategies to render their inner experience and to convey to reader's elements of atrocity that evaded more chronological or historical narratives. These literary representations grapple with the philosophical, psychological and cultural implications of the Holocaust. While most fiction works, written by male survivors, place women at the edge, most women's literature focuses on women, highlighting both the commonality and differences in Jewish men's and women's experiences. Gender specific topics include a focus on childbirth and motherhood during the war. During the Holocaust, responsibility for children placed a special burden on mothers, who struggled to sustain the family despite the genocidal pressures that made this difficult. Among the most powerful and subtle fiction writers, British writer and journalist Wendy Holden (1961) draws a sad destiny of women whose husbands murdered by the Nazis in the documentary novel Born Survivors (2015). Being concentration camp prisoners Priska, Rachel, and Anka would not let evil take their unborn children too - a remarkable true story that will appeal to readers of three mothers who defied death to give their children life. The novel focuses on three women who believe they are pregnant, but are torn from their husbands before they can be certain. Rachel is sent to Auschwitz, unaware that her husband has been shot. Priska and her husband travel there together, but are immediately separated. Also at Auschwitz, Anka hopes in vain to be reunited with her husband. With the rest of their families gassed, these young wives are determined to hold on to all they have left - their lives, and those of their unborn babies. Having concealed their condition from infamous Nazi doctor Josef Mengele, they are forced to work and almost starved to death, living in daily fear of their pregnancies being detected by the SS. In the beginning of 1945, Priska gives birth. She and her baby, along with Anka, Rachel, and the remaining inmates, are sent to Mauthausen concentration camp on a hellish 17-day train journey. Rachel gives birth on the train, 
and Anka at the camp gates. All believe they will die, but then a miracle occurs. The gas chamber runs out of Zyklon-B, and as the allied troops near, the SS flee. Against all odds, the three mothers and their newborns survive their treacherous journey to freedom.

It is significant that some prosaic works ruin above-mentioned cold-bloodiness and cruelty of German people towards Jews; the reason for this is that there were generous and sympathetic Germans in the history of the Holocaust. The first and the greatest example is the novel Schindler's Ark (1982) by Australian novelist Thomas Keneally (1935). "The book tells the story of Oskar Schindler, a Nazi Party member who turns into an unlikely hero by saving 1,200 Jews from concentration camps all over Poland and Germany. It is a work of historical fiction that describes real people and places with fictional events, dialogues and scenes added by the author and reconstructed dialogues where exact details are unknown. Keneally wrote a number of well received novels before and after Schindler's Ark, however it has since gone on to become his most wellknown and celebrated work" [1]. Holy books claimed that "He who saves a single soul, saves the world entire". Oskar was one of them, who had courage to save more than thousand representatives of the Jewish nation.

However, there is another novel Irena's Children (2016) by British historian and writer Tilar J. Mazzeo (1971). She draws a touching story of Polish social worker Irena Sendle — the "female Oskar Schindler" - who took staggering risks to save 2,500 children from death and deportation in Nazi-occupied Poland during the World War II. Irena Sendler, was granted access to the Warsaw ghetto as a public health specialist. While she was there, she began to understand the fate that awaited the Jewish families who were unable to leave. Soon she reached out to the trapped families, going from door to door and asking them to trust her with their young children.

Driven to extreme measures and with the help of a network of local tradesmen, ghetto residents, and her star-crossed lover in the Jewish resistance, Irena ultimately smuggled thousands of children past the Nazis. She made dangerous trips through the city's sewers, hid children in coffins, snuck them under overcoats at checkpoints, and slipped them through secret passages in abandoned buildings. Nevertheless, Irena did something even more astonishing at immense personal risk: she kept a secret list buried in bottles under an old apple tree in a friend's back garden. On it were the names and identities of these Jewish children, recorded so their families could find them after the war. She could not know that more than 90 percent of their families would perish. Chaya Deitsch, (the author of Here and There: Leaving Hasidism, Keeping My Family), described Irena's Children as "a fascinating narrative of... the extraordinary moral and physical courage of those who chose to fight inhumanity with compassion" [1, p. 180] and the novel is a truly heroic tale of survival, resilience, and redemption.

Furthermore, Art Spiegelman (1948), an American writer and cartoonist has created a graphic novel Maus (1991) that reveals the Jewish hard times explicitly, which later is awarded a Pulitzer Prize. What is interesting in this work is that various nationalities are presented in the form of different animals - Germans as cats, Poles as pigs, and Jews as the mice giving the name to the novel. As being the son of a Polish Jew family, Art succeeded to give a clear picture of his family particularly, his father's personal experience during WWII. Maus is a haunting tale within a tale. Vladek Spiegelman's harrowing story of survival is woven into the author's account of his tortured relationship with his aging father. Against the backdrop of guilt brought by survival, they stage a normal life of small arguments and unhappy visits. Maus studies the bloody pawprints of history and tracks its meaning for all of us. This is not only one of the greatest graphic novels ever written, but it is also one of the most important and influential the Holocaust books ever published.

There is a great deal of prosaic works about the Holocaust phenomenon that have not even entirely been analyzed in this research, but are read all over the world. This theme still stays as one 
of the most interesting as the Holocaust remained excessive memories, events, tears and sorrows in the world history. Yet Elie Wiesel, an American novelist has played a major role in the spreading of the theme of the Holocaust. Some even argue that he was the first to coin the term to typify the Jewish genocide via his literary legacy.

\section{Conclusions}

The theme of Holocaust is treated variously by a lot of authors across the world. It is not shocking news that novels, poems, plays, memoirs were created in different languages and styles focusing on the Jewish extermination during the Second World War. This research work focuses on the reflection of the Holocaust in world literature, yet it is not limited by identifying only this very theme in different works, but we have also developed a system of classification of novels according to the types of narrators, as narrators' gender, age, nationality obviously had an impact on the storyline.

As much as the novels are books of witnesses, the voice of a rebellion that some of the authors could not express at the time of their imprisonment, should not be considered as a revolt against God but against the human brutality to which they had once been forced to submit. It is the reverberating echo of the cry they could not utter, all the louder now because it was silenced then.

The research was aimed to evaluate the theme of the Holocaust in creative works of world authors and focus on their contribution to portray Holocaust phenomena as a long lasting pain reflected in world literature. So we made the conclusion that such genocide actions initiated by Nazis and their reflection in literature are essential to be taken for analysis as such works written on the theme of Holocaust reopen and remind readers about the atrocities of the fascism as well as not to pass by such crimes in near future.

\section{Sources:}

1. Kerry J. Remembering the Past, Safeguarding the Future. 2000.

2. Lang, B. (1999). Translating the Holocaust: For whom does one write? Judaism, 48(3), 334.

3. Steiner, G. (1998). Language and silence: Essays on language, literature, and the inhuman. Yale University Press.

4. Sara R. Horowitz. https://www.ushmm.org/research/publications/journal

5. Segev, T. (2000). The seventh million: The Israelis and the Holocaust. Macmillan.

\section{References:}

1. Deitsch, C. (2015). Here and there: Leaving hasidism, keeping my family. Schocken.

2. Rajchman, C. (2012). The Last Jew of Treblinka: A Memoir. Open Road Media.

Работа поступила

в редакциюю 08.03.2020 г.
Принята к публикацчии

11.03.2020 2.

Ссылка для циитирования:

Mukhamedova Sh. World Literature on the Destiny and Sufferings of Jewish People // Бюллетень науки и практики. 2020. Т. 6. №4. С. 562-569. https://doi.org/10.33619/2414$2948 / 53 / 67$

Cite as (APA):

Mukhamedova, Sh. (2020). World Literature on the Destiny and Sufferings of Jewish People. Bulletin of Science and Practice, 6(4), 562-569. https://doi.org/10.33619/2414-2948/53/67 (in Russian). 